\title{
POTENSI WISATA DI LAMPUNG DAN pengembangannya
}

\section{THE POTENCY OF TOURISM IN LAMPUNG AND ITS DEVELOPMENT}

\author{
Oleh Ani Rostiyati \\ Balai Pelestarian Nilai Budaya Bandung \\ Jl. Cinambo No. 136 Ujungberung - Bandung \\ Email :anirostiyati@yahoo.com
}

\begin{abstract}
Abstrak
Lampung sebagai salah satu provinsi di Indonesia memiliki potensi alam dan budaya yang bisa dikembangkan sebagai objek wisata. Potensi tersebut antara lain alam yang indah dan hawa sejuk, dikelilingi oleh kehijauan bukit dan gunung yang banyak ditumbuhi aneka ragam bunga dan pohon. Aneka ragam budayanya juga terlihat unik dan menarik, demikian pula adat istiadatnya. Dengan kondisi demikian maka Lampung bisa dijadikan mata rantai tujuan wisata Masalahnya adalah potensi tersebut belum tergarap sepenuhnya, oleh sebab itu perlu kajian secara mendalam bagaimana potensi dan pengembangannya. Dari hasil identifikasi potensi wisata yang ada di Lampung, maka akan dikaji bagaimana strategi pengembangannya dengan melihat semua komponen produk wisata yakni meliputi atraksi, amenitas, akses, dan ancillary service. Komponen produk wisata kemudian dinilai dengan analisis SWOT (strenghts, weaknesses, opportunities, threats) untuk melihat strategi yang digunakan dalam pengembangan pariwisata. Analisis SWOT digunakan pada data yang tidak menggunakan angka (kualititatif) dan digunakan sebagai dasar dalam perumusan kebijakan. Dengan demikian yang menjadi ruang lingkup kajian ini adalah : mengungkapkan potensi budaya, termasuk juga potensi alam, religi, dan sejarah; melihat sarana dan prasarana yang mendukung kegiatan pariwisata; sikap dan perilaku masyarakat setempat dalam menyikapi masalah kepariwisataan.
\end{abstract}

Kata kunci: pengembangan, potensi wisata, Lampung.

\begin{abstract}
Lampung has great natural and cultural potencies that could be developed as objects of tourism: beautiful landscapes, moderate weather and various vegetations with mountains and hills surrounding it. Not to mention various unique customs and cultural heritage. Unfortunately, these potencies have not been fully developed yet for the benefit of its people. By using SWOT (strengths, weaknesses, opportunities, threats) analysis, the
\end{abstract}


author reviewed all components of tourism, such as attractions, amenities, access, and ancillary services. The aim of this study is to reveal cultural, natural, religious, and historical potencies as well as facilities and infrastructure that would support tourism activities, attitude and behavior of the local community in dealing with problems in tourism.

Keywords: development, tourism potency, Lampung.

\section{A. PENDAHULUAN}

Sektor pariwisata saat ini semakin berperan dalam menunjang pembangunan nasional maupun daerah. Sejak tahun 1997 diharapkan sektor pariwisata menjadi sumber andalan devisa negara di luar sektor nonmigas. Pemerintah dalam pengembangan pariwisata melalui Direktorat Jenderal Kebudayaan dan Pariwisata menegaskan bahwa :

"Dalam rangka pembangunan nasional, guna meningkatkan kesejahteraan rakyat, GBHN telah menetapkan bahwa pembangunan kepariwisataan dilanjutkan dan ditingkatkan dengan mengembangkan dan mendayagunakan sumber dan potensi kepariwisataan nasional menjadi kegiatan ekonomi yang diandalkan untuk memperbesar penerimaan devisa, memperluas dan meratakan kesempatan berusaha dari lapangan kerja terutama bagi masyarakat setempat, mendorong pembangunan daerah serta memperkenalkan alam, nilai dan budaya bangsa."

Untuk mencapai target tersebut, maka kegiatan pariwisata perlu ditingkatkan, karena selain menambah devisa negara, juga memperluas lapangan kerja dan memperkenalkan aneka ragam kebudayaan serta alam Indonesia yang indah. Indonesia mempunyai potensi yang besar dalam pengembangan pariwisata, karena selain memiliki alam yang indah juga aneka ragam budaya dan adat istiadat. Sayangnya, potensi ini belum tergarap secara optimal, mungkin karena alasan dana atau sumber daya manusianya yang belum siap. Untuk itu, pemerintah saat ini berupaya menggali potensi alam atau budaya yang bisa dipakai sebagai tujuan wisata.

Lampung sebagai salah satu provinsi di Indonesia juga memiliki potensi alam dan budaya yang bisa dikembangkan sebagai objek wisata. Potensi tersebut antara lain alam yang indah dan hawa sejuk, dikelilingi oleh kehijauan bukit dan gunung yang banyak ditumbuhi aneka ragam bunga dan pohon. Aneka ragam budayanya juga terlihat unik dan menarik, demikian pula adat istiadatnya. Dengan kondisi demikian maka Lampung bisa dijadikan mata rantai tujuan wisata.

Keindahan alam dan budaya di Lampung memang sebagian sudah digarap dengan baik, artinya sudah dijadikan sebagai tujuan wisata. Namun, bila dibandingkan dengan potensi yang ada tampaknya pariwisata di Lampung belum digali secara optimal. Masih cukup banyak potensi alam dan budaya di daerah Lampung yang belum digarap secara serius.

Lampung adalah kota yang strategis bagi kunjungan wisata ke berbagai objek wisata. Kota ini bisa dicapai dalam 1,5 jam dari Bakauheni dan 30 menit dari Bandar Udara Radin Inten. Objek wisata pantai, budaya, alam pegunungan, hutan, sungai, selam dan memancing, mudah dijangkau dari kota ini. Objek yang satu dan lainnya saling berdekatan, bisa dipastikan kunjungan atau perjalanan wisata menjadi tidak monoton, pengalaman pun menjadi lebih beragam karena banyak tempat yang bisa dilihat.

Provinsi Lampung terdiri atas 13 kabupaten dan 2 kotamadya yakni Kota Bandar Lampung dan Metro. Ibukota Lampung berada di Bandar Lampung dan 
menurut sejarahnya Bandar Lampung merupakan penyatuan dari dua kota, yakni Telukbetung dan Tanjungkarang. Telukbetung dan Tanjungkarang dianggap merupakan cikal bakal terbentuknya Kota Bandar Lampung. Secara geografis, Teluk Betung berada di selatan Tanjung Karang dan dijadikan patokan batas jarak Ibukota Provinsi. Pada tahun 1984, Kota Teluk Betung dan Tanjung Karang digabung dalam satu kesatuan wilayah kota di Bandar Lampung. Pada perkembangan selanjutnya, Kota Tanjung Karang dan Teluk Betung berubah menjadi Kotamadya TK. II Tanjung Karang-Teluk Betung dan sekaligus menjadi Ibukota Provinsi Lampung. Pada tahun 1988 berdasarkan PP no 43 terjadi perubahan penyebutan dari pemerintah Kotamadya DT II Bandar Lampung menjadi pemerintah Kota Bandar Lampung dan tetap dipergunakan hingga saat ini.

Ada tujuh wisata unggulan yang terdapat di Lampung, yakni Krakatau, Bandar Lampung (Teluk Betung dan Tanjung Karang), Kiluan (laut yang terdapat banyak ikan lumba-lumba di Kabupaten Tanggamus), Bukit Barisan Selatan, Way Kambas, Tanjung Setra, dan menara Siger. Khusus untuk Teluk Betuk dan Tanjung Karang yang sudah digabung dalam satu kesatuan yang menjadi pusat ibukota Lampung ini memiliki potensi wisata unggulan seperti adanya museum yang terletak di tengah kota, sentra kerajinan tapis, sentra penjualan kuliner keripik pisang, dan berbagai sanggar seni. Pengembangan wisata unggulan ini sudah dikemas dengan baik dan menjadi tujuan wisatawan. Adapun pantai, laut, rumah tradisioal, danau, alam pegunungan, biasanya terletak jauh dari ibukota Lampung dan ini merupakan wisata nonunggulan.

Wisata nonunggulan sebenarnya cukup banyak di Provinsi Lampung, akan tetapi belum tergarap sepenuhnya, meskipun prasarana dan sarana cukup tersedia, seperti taksi, bus dalam kota dan antarkota, kereta api, restoran, penginapan, dan pusat perbelanjaan. Dengan kondisi seperti itu, maka Lampung memiliki potensi alam dan budaya yang dapat dimanfaatkan untuk tujuan wisata. Yang menjadi pokok permasalahan adalah potensi daerah tersebut belum digali secara mendalam, terutama pada wisata nonunggulan. Selain itu, kesadaran masyarakat akan kekayaan budaya yang mendukung industri pariwisata dirasa kurang, padahal kegiatan pariwasata sesungguhnya merupakan pariwisata sosial budaya yang melibatkan unsur manusia (SDM) di dalamnya. Artinya perlu didukung oleh sikap perlaku sadar wisata yang mendukung kegiatan tersebut.

Penelitian kecil ini dilakukan dalam upaya menjawab pertanyaan tersebut, yakni ingin melihat bagaimana potensi pariwisata di Lampung dan pengembangannya. Langkah pokok dalam melihat potensi dan pengembangan objek daerah tujuan wisata (ODTW) adalah lewat identifikasi objek wisata. Dalam mengidentifikasi memperhatikan 3 hal yaitu kriteria untuk mengidentifikasi, metode identifikasi dan dokumentasi hasil identifikasi. Objek wisata yang teridentifikasi, kemudian dikaji dengan analisis SWOT untuk melihat kekuatan, kelemahan, ancaman dan peluang untuk pengembangan kawasan wisata tersebut. Semua objek wisata akan dilakukan penilaian meliputi kriteria keragaman atraksi, latar lingkungan alam budaya, tingkat kelola lingkungan, hubungan antara objek wisata, aksebilitas, fasilitas, pasar kelembagaan, dan SDM. Selanjutnya hasil dari penilaian semua komponen objek wisata akan dikaji dengan menggunakan analisis SWOT, yakni merupakan salah satu alat menganalisis kekuatan (strength), kelemahan (weakness), peluang (opportunity) dan ancaman (threat) suatu objek. Analisis SWOT digunakan pada data yang tidak menggunakan angka (kualititatif) dan digunakan sebagai dasar dalam perumusan kebijakan. Dengan demikian yang menjadi ruang lingkup kajian ini adalah : mengungkapkan potensi 
budaya, termasuk juga potensi alam, religi, dan sejarah; melihat sarana dan prasarana yang mendukung kegiatan pariwisata; sikap dan perilaku masyarakat setempat dalam menyikapi masalah kepariwisataan.

\section{B. HASIL DAN BAHASAN}

Lampung termasuk provinsi yang memiliki objek wisata yang menarik atau bisa dijual, baik alam maupun dikelilingi oleh kehijauan bukit dan gunung yang banyak ditumbuhi beraneka ragam bunga. Oleh sebab itu Lampung sejak lama dijadikan mata rantai tujuan wisata karena memiliki potensi budaya alam yang memesona. Dengan kondisi alam tersebut menjadikan Lampung sebagai salah satu tujuan wisatawan baik dari dalam maupun luar negeri. Meskipun potensi alam dan budaya di daerah tersebut belum digali sepenuhnya, namun di sana terdapat pantai, laut, perkebunan, pegunungan dan hutan, peninggalan sejarah, kuliner yang bisa dijadikan tujuan wisata. Selain itu, tumbuh suburnya berbagai kesenian daerah dan adat istiadat khas Lampung bisa dijadikan sebagai aset wisata.

Membangun industri pariwisata memang tidak hanya cukup dengan keindahan alam dan keragaman budaya saja, melainkan juga harus didukung oleh sarana lainnya seperti jasa usaha, transportasi, dan faktor kesiapan sumber daya manusia dalam menunjang pariwisata. Betapa pentingnya keterlibatan masyarakat dalam menunjang pariwasata tersebut. Daya tarik dan potensi daerah tujuan wisata akan berhasil dengan dukungan prasarana, sarana dan kesiapan masyarakat sebagai sumber daya manusia yang terlibat dalam industri pariwisata. Sebab bagaimanapun juga kegiatan pariwisata merupakan pariwisata sosial budaya yang melibatkan unsur manusia di dalamnya (Donald E. Linberg, 1976: 102).

Menurut Donald untuk mewujudkan masyarakat industri pariwisata perlu didukung oleh sikap perilaku dan nilainilai budaya yang mendukung kegiatan tersebut. Oleh sebab itu dalam industri pariwisata, unsur manusia menjadi sentral perhatian baik dia sebagai objek maupun subjek. Kemasan pariwisata tidak bisa ditampilkan terpilah-pilah atau terlepas dari unsur manusianya, melainkan harus merupakan suatu kesatuan utuh yang diwujudkan dengan pelayanan, keramahtamahan, kebersihan, keamanan, keindahan dan ketertiban yang ditampilkan oleh masyarakat pendukungnya.

Bandar Lampung adalah kota yang strategis bagi kunjungan wisata ke berbagai objek wisata. Kota ini bisa dicapai dalam 1,5 jam dari Bakauheni dan 30 menit dari Bandar Udara Radin Inten. Objek wisata pantai, budaya, alam pegunungan atau wisata petualangan di hutan dan sungai, selam dan memancing, mudah dijangkau dari kota ini. Objek yang satu dan lainnya saling berdekatan, bisa dipastikan kunjungan atau perjalanan wisata menjadi tidak monoton, pengalaman pun menjadi lebih beragam karena banyak tempat yang bisa dilihat.

Selain itu rumah-rumah tradisional atau rumah adat, kawasan hutan kota dan taman kupu-kupu bisa dilihat di sini. Di banyak tempat di Lampung bisa dengan mudah menemukan kain tapis, yaitu kain khas Lampung yang ditenun dari benang, kapas atau serat nanas secara tradisional. Kain yang disulam dengan benang emas atau benang perak yang dinamakan tapis dan sulam usus juga dijumpai di Lampung dengan berbagai motif.

Jika ingin wisata pantai, bisa datang ke bibir Pantai Teluk Lampung yang terbentang dari Kalianda di Lampung Selatan hingga Bandar Lampung. Sebuah kawasan teluk dengan pantai yang indah dan selanjutnya ke Teluk Semangka di Tanggamus. Sumber air panas Way Belerang, Pantai Wartawan, Kalianda Resor, Laguna Helau, Merak Belantung, Pasir Putih, Tanjung Selaki, Pulau Pasir, Pantai Marina adalah kawasan wisata pantai di Teluk Lampung di wilayah Lampung Selatan. Pantai Marina memiliki pemandangan indah dengan batu-batu 
karang yang bentuknya beraneka ragam. Menurut cerita rakyat, ada batu karang yang disebut Batu Balai merupakan tempat Pangeran Cindar Bumi menerima tamu. Pantai ini terletak di Kecamatan Sidomulyo, 43 kilometer dari Bandar Lampung atau 22 kilometer dari Kalianda. Fasilitas yang tersedia di sini beragam. Sedangkan kawasan wisata Kalianda Resort terletak 30 kilometer utara Bakauheni, 20 kilometer utara Kalianda, dan 45 kilometer dari Bandar Lampung. Kawasan ini menyediakan fasilitas petualangan seperti tur ke Krakatau dan pulau-pulau sekitar Teluk Lampung bagian selatan, diving di Pulau Sebuku, memancing, tempat berkemah, bungalow, jetsky, diskotek, kafetaria yang menghadap ke pantai, penyewaan sepeda, dan perahu dayung.

Objek-objek wisata lain adalah taman purbakala, desa adat, agrowisata, makam Kuno Pangeran Jiwa Kesuma, kawasan batu keramat, air terjun, kubu perahu, danau dan perkampungan asli yang tersebar di 10 kabupaten dan kota. Objekobjek wisata itu hanyalah sebagian kecil dari kekayaan objek wisata Lampung. Wisata unggulan di Lampung adalah objek wisata Kepulauan Gunung Krakatau, Taman Nasional Way Kambas dan Bukit Barisan. Tiga objek ini sudah dikenal di seluruh dunia. Di samping objek fisik, pariwisata Lampung juga menyajikan paket atraksi yang puncaknya adalah Festival Krakatau.

Lampung merupakan kawasan wisata alternatif yang paling diminati warga Jakarta dan daerah lain di Sumatera. Setiap akhir pekan sebagian hotel di Lampung, mulai dari hotel melati hingga hotel berbintang, selalu padat tamu. Tingkat hunian hotel di Lampung bisa mencapai di atas 50 persen. Sebagian besar tamu hotel datang dari Jakarta dan sekitarnya, seperti Serang dan sebagian kecil dari Palembang atau Bengkulu. Sejak tahun 2002, tingkat hunian hotel mulai padat sejak Jumat malam.

\section{Potensi Kawasan Wisata di Lampung dan Pengembangannya}

Pariwisata merupakan sebuah bentuk kegiatan rekreasi. Sebagai kegiatan rekreatif, pariwisata merupakan sarana pemenuhan hasrat manusia untuk bereksplorasi guna mengalami berbagai perbedaan. Karakter yang melekat dari sebuah kegiatan wisata adalah melakukan perjalanan ke luar wilayah kehidupan sehari-hari. Unsur perjalanan menjadi penting yang bertujuan mengalami perbedaan fisik, seperti bangunan, lingkungan alam, benda, hewan, tumbuhan, dan manusia. Perbedaan nonfisik seperti perbedaan suhu, udara, kuliner, suasana, adat istiadat, kesenian, cara berpakaian, dan lain sebagainya.

Karakter pariwisata lainnya dilakukan dalam jangka waktu relatif pendek atau tidak terlalu lama. Ketika mereka sudah puas memperoleh pengalaman dan berbagai perbedaan yang dijumpai di suatu tempat, dengan segera mereka kembali pada kesehariannya. Kegiatan pariwisata merupakan sebuah interaksi sosio kultural sebab di dalamnya terkandung interaksi antara host (tuan rumah) dengan guests (wisatawan). Dalam kaitannya dengan apa yang dinikmati oleh konsumen atau wisatawan dalam kegiatan pariwisata dikenal dengan nama produk wisata. Produk wisata dapat diartikan sebagai sesuatu yang dapat "dijual" sebagai komoditas pariwisata. Produk wisata sebagai komponen penting dalam industri pariwisata mencakup 3 aspek yang dikenal dengan istilah triple A (atraksi, amenitas, aksesbilitas, dan ancillary service).

Atraksi adalah objek atau daya tarik wisata (ODTW) yang bisa dilihat, ditonton, dan dinikmati oleh wisatawan. Seringkali atraksi ditafsirkan dalam dua komponen yakni sebagai objek wisata dan atraksi wisata. Objek wisata biasanya dapat disaksikan tanpa perlu persiapan, sedangkan atraksi wisata adalah sesuatu yang dapat dilihat lewat pertunjukan dan seringkali membutuhkan persiapan. 
Selain atraksi, yang termasuk dalam produk wisata adalah amenitas yakni segala macam fasilitas yang menunjang kegiatan pariwisata seperti rumah makan, penginapan, komunikasi, pos keamanan dan lain sebagainya. Keberadaan dan kelengkapan berbagai jenis fasilitas menjadi syarat mutlak bagi kunjungan wisatawan. Ketiga adalah aksesbilitas berupa sarana yang menyebabkan wisatawan dapat berkunjung di sebuah objek wisatawan. Dalam konteks ini, sarana dan prasarana dibangun agar wisatawan dapat mencapai tujuan dengan aman, nyaman, dan layak. Alat transportasi mudah dicari dan keadaan jalan mudah dilalui, sehingga akses wisatawan ke tujuan wisata bisa dicapai dengan mudah, aman, dan nyaman. Terakhir adalah ancillary service yakni meliputi kegiatan pemasaran, promosi, dan koordinasi.

Dari keempat aspek produk wisata di atas, model pengembangan produk haruslah mempertahankan keaslian agar dapat bersaing dengan daerah lain. Dengan kata lain, objek wisata harus memiliki keunikan tersendiri yang berbeda dengan objek wisata lain. Keunikan merupakan faktor penting dalam menentukan penjualan. Selain itu, dukungan kondisi prasarana yang baik, tersedianya fasilitas, dan pelayanan juga menentukan daya tarik wisata.

Selain yang disebutkan di atas, potensi wisata juga perlu didukung oleh sikap dan nilai-nilai budaya yang mendukung kegiatan tersebut. Unsur manusia menjadi sentral perhatian, baik sebagai objek maupun subjek. Peranan masyarakat dalam pengembangan pariwisata sangat penting yakni harus memiliki sikap mental, perilaku, dan nilai budaya yang mampu mewujudkan masyarakat industri pariwisata. Usaha pariwisata dapat dianggap usaha industri karena memperdagangkan barang dan jasa. Oleh sebab itu industri pariwisata tidak bisa dilepaskan dari peran serta masyarakat dan sumber daya manusia yang terlibat langsung di dalamnya. Masyarakat diharapkan mampu melaksanakan Program Sapta Pesona, meliputi keamanan, kebersihan, ketertiban, keindahan, ramah tamah, sejuk, dan kenangan. Masyarakat diharapkan mempunyai sikap mental dan nilai-nilai budaya yang mendukung Program Sapta Pesona tersebut.

Berikut ini akan dipaparkan potensi nilai budaya masyarakat di satuan lokasi wisata Lampung, dimana aspek nilai budaya daerah dijadikan sebagai acuan dalam pengembangan pariwisata. Kebudayaan dapat diartikan sebagai suatu cara hidup atau way of life. Cara hidup atau pandangan hidup ini meliputi cara berpikir, bertindak, dan karya nyata yang dianggap berguna bagi masyarakatnya. Pengertian kebudayaan daerah di sini adalah sistem nilai budaya yang berfungsi untuk menata perilaku dan menghasilkan benda atau hasil karya masyarakat. Sistem nilai budaya merupakan suatu rangkaian dan konsepsi abstrak yang hidup dalam alam pikiran masyrakat tentang yang dianggap penting dan berharga.

Masyarakat Lampung memiliki seperangkat nilai budaya yang merupakan adat dan hasil sosialisasi keluarga maupun lingkungan sosialnya. Sejak kecil, mereka sudah ditanamkan sikap ramah dan terbuka. Sikap dan tingkah laku masyarakat Lampung pada dasarnya tercermin pada falsafah piil pesenggiri. Secara harfiah, piil pesengiri berarti perbuatan atau perangai manusia yang agung dan luhur di dalam nilai serta maknanya dan karena itu patut diteladani dan pantang untuk diingkari. Di dalam konsep piil pesenggiri terkandung nilainilai budaya luhur yang mengandung makna berjiwa besar, malu, harga diri, ramah, suka bergaul, tolong menolong, bernama besar dan bergelar. Oleh sebab itu untuk mempertahankan piil pesenggiri, seseorang dapat mempertahankan apa saja, sekalipun nyawa. Sebagai prinsip hidup bermayarakat bagi orang Lampung piil pesenggiri didukung dan ditunjang oleh 4 unsur, yakni sakai sambaian, nemui nyimah, nengah nyappur, dan berjuluk 
beadek. Sakai sambaian artinya tolong menolong di antara sesama silih berganti. Tolong menolong ini tidak bersifat materiil saja, tapi juga moral termasuk tenaga dan pikiran. Inti dari konsep ini terletak pada kegiatan individual untuk memenuhi kepentingan umum dan tidak didasarkan kepentingan pribadi.

Unsur kedua adalah nemui nyimah, yakni nemui membuka diri untuk menerima tamu dan nyimah artinya keinginan untuk memberikan sesuatu dengan ikhlas pada seseorang atau kelompok sebagai tanda akrab. Jadi nemui nyimah artinya bermurah hati dan ramah tamah, sopan santun, dan menghargai orang lain (tamu). Inti dari konsep ini adalah sikap bermurah hati dengan memberikan sesuatu kepada orang lain, bermurah hati, bertutur kata sopan santun. Unsur ketiga adalah nengah nyappur yakni suka berkenalan, bersahabat, dan bergaul dengan masyarakat. Intinya konsep ini diartikan sebagai keterbukaan, berpengetahuan luas, dan ikut berpartisipasi terhadap segala hal yang baik. Nilai nengah nyappur mengharuskan tiap individu baik kepada orang lain, menjaga keseimbangan antara kepentingan pribadi dan umum. Bejuluk deadek adalah pemberian gelar untuk menghormati orang lain akan jasa dan peranannya. Selain itu juga diberikan kepada orang atau kerabat yang diatur oleh adat secara turun menurun. Pemberian gelar ini dilakukan dengan upacara adat.

Dari uraian tentang piil pesenggiri ini tergambar bahwa konsep tersebut merupakan pandangan hidup yang bersifat mempertahankan harga diri. Budaya harga diri bagi masyarakat Lampung pepadun merupakan budaya malu dalam wujud tradisional seperti tercermin dalam piil pesenggiri. Sebagai pedoman bersikap dan bertingkah laku, piil pesenggiri telah menyatu dalam kehidupan sosial masyarakat Lampung dan merupakan satu totalitas dari bentuk kehidupan, perasaan, pengalaman, dan kehendak sehingga menjadi karakter khas manusia Lampung.
Mereka berprinsip piil pesenggiri menjaga kesadaran moral untuk mencapai kebahagiaan hidup, mengembangkan keserasian, keselarasan, dan kesadaran hidup masyarakat.

Dalam kaitannya dengan pariwisata, Piil Pesenggiri berdampak positif yakni nilai-nilai yang terkandung di dalamnya seperti keterbukaan, ramah, tolong menolong, menghargai orang lain, punya harga diri, dan malu, bisa menjadi faktor pendukung Sapta Pesona Wisata, yaitu ketertiban, keindahan, ramah, sejuk, bersih, keamanan, dan kenangan. Berikut ini diuraikan tentang nilai budaya daerah yang berkaitan dengan Sapta Pesona Pariwisata yakni ramah, aman, tertib, indah, bersih, sejuk, dan kenangan. Ramah adalah sikap yang selalu ditanamkan pada setiap orang dalam berkomunikasi. Sikap ramah erat kaitannya dengan rasa hormat dan sopan, suka senyum dan suka membantu tanpa pamrih. Aman adalah sikap yang memberi rasa tenang dan tentram bagi masyarakat. Makna yang terkandung dalam ungkapan tersebut adalah kita tidak boleh percaya begitu saja kepada orang lain, harus hati-hati dan waspada. Untuk menciptakan rasa aman bagi wisatawan, dibangun beberapa pos yang dijaga oleh satpam. Untuk mempermudah keamanan, petugas mengeluarkan peraturan pada setiap pemilik penginapan agar selalu melaporkan tamunya pada ketua RT setempat.

Tertib adalah suatu kondisi atau keadaan yang mencerminkan suasana teratur dan disiplin. Tertib erat kaitannya dengan etos kerja. Masyarakat Lampung selalu berprinsip jangan meninggalkan pekerjaan yang belum selesai. "Berjalan sampai ke batas, berlayar sampai ke pulau", begitu kata peribahasa, dalam mengerjakan tugas harus sampai selesai secara teratur dan disiplin. Budaya antri berkaitan dengan sikap tertib masyarakat, artinya jika masyarakat tertib dan taat peraturan, maka timbul budaya antri dalam membeli tiket dan berlalu lintas. Tertib 
mengenai waktu juga selalu ditanamkan masyarakat, jangan lupa pada waktu. Tertib dalam waktu merupakan kunci sukses dalam hidup, karena dengan mengerjakan pekerjaan tepat waktu akan menghasilkan optimal. Demikian pula dalam membuat janji, masyarakat Lampung harus menepati janji, harus teguh memegang janji dan tidak pernah melanggar janji. Nilai budaya tertib memberi kontribusi positif terhadap program Sapta Pesona Pariwisata di Lampung, yakni masyarakat harus tepat waktu, menepati janji, antri, dan disiplin. Untuk menjaga ketertiban pengunjung, di tempat tertentu sekitar pantai dipasang tulisan "Jangan buang sampah sembarangan", "di sini tempat parkir", "Jangan berenang berbahaya", dan lain sebagainya. Semua tulisan itu untuk mengingatkan pengunjung agar bersikap tertib.

Indah adalah suatu kondisi yang mencerminkan penataan yang teratur, tertib, dan serasi sehingga memancarkan keindahan. Masyarakat Lampung, senang akan keindahan baik dalam penampilan dan penataan yang serasi hingga memancarkan keindahan. Nilai budaya indah yang ada pada masyarakat Lampung ternyata memberi kontribusi positif pada pelaksanaan program Sapta Pesona Pariwisata.

Sikap bersih juga ditanamkan pada masyarakat Lampung, keadaan bersih ini harus tercermin dalam lingkungan maupun diri sendiri. Ungkapan yang sering ditanamkan pada masyarakat adalah hidup itu harus besih dan sehat. Dengan bersih jasmani maupun rohani, akan menjadikan badan sehat dan jauh dari penyakit. "Kebersihan merupakan bagian dari iman", ungkapan ini sangat diresapi masyarakat Lampung. Mereka melakukan kerja bakti Jumsih, yakni pada hari Jumat dilaksanakan kerja bakti agar lingkungan sehat dan bersih. Selain itu pada hari Minggu mereka melaksanakan kerja bakti untuk membersihkan fasilitas umum seperti selokan, jalan, parit, mesjid, dan makam. Nilai budaya bersih ini memberi kontribusi positif dalam melaksanakan program Sapta Pesona Pariwisata. Masyarakat diharapkan senantiasa menjaga kebersihan lingkungan, sehingga terlihat bersih, rapi, dan nyaman. Kondisi ini tentu akan membuat wisatawan merasa betah, nyaman, bebas sampah, limbah, dan kotoran lain.

Kenangan adalah sesuatu yang memberi kenyamanan dan kepuasan sehingga orang punya kesan mendalam. Sudah merupakan tradisi jika masyarakat Lampung memberi oleh-oleh tamu atau sanak saudara untuk kenangan, sebagai rasa hormat, ucapan terima kasih, dan menyambung tali persaudaraan. Beberapa warga membuat gantungan kunci, bingkai foto, guci, asbak dari kayu. Kayu biasanya didapat dari limbah laut saat kayu tersebut terdampar ke tepi pantai. Memberi kenangan merupakan tradisi yang baik, karena memberikan oleh-oleh pada tamu untuk mengungkapkan rasa hormat, ucapan terima kasih, dan memberikan kesan mendalam kepada orang lain. Tradisi ini berdampak positif bagi dunia wisata, karena kenangan itu mempunyai makna yang beragam, terkesan karena pelayanannya, keindahan alamnya, kebersihan lingkungannya, keseniannya, kuliner, atau cinderamata yang unik menarik.

Sejuk adalah suatu kondisi atau keadaan lingkungan yang memberikan suasana segar dan nyaman. Kondisi itu sudah tercipta di kawasan wisata di Lampung. Keindahan alamnya, sungguh menarik bagi wisatawan, udara sejuk, pemandangan alam yang indah, hamparan pasir yang memikat. Potensi alam yang dimiliki ini merupakan aset utama untuk mengembangkan pariwisata di Lampung.

Apa yang sudah diuraikan di atas bahwa kebudayaan daerah mempunyai peranan penting dalam pengembangan pariwisata. Artinya, bahwa untuk mewujudkan masyarakat industri pariwisata perlu didukung oleh sikap mental, perilaku, dan nilai-nilai budaya 
yang mendukung kegiatan tersebut. Masyarakat Lampung memiliki nilai-nilai budaya yang mampu mendasari pelaksanaan program sapta pesona wisata. Piil pesenggiri yang merupakan falsafah hidup orang Lampung sangat berperan dalam mewujudkan sikap mental, nilainilai, dan perilaku yang mendukung pengembangan pariwisata.

Setelah melihat potensi objek wisata di satuan kawasan wisata di Lampung, maka dalam rancangan pengembangan terlebih dahulu perlu dilakukan penilaian semua komponen objek wisata di Lampung, terutama wisata nonunggulan. Khusus untuk wisata unggulan yang berada di Bandar Lampung (Tanjungkarang dan Telukbetung) sudah tertata dengan baik sarana maupun prasarananya. Berikut ini hasil dari identifikasi potensi wisata di Lampung, yakni :

1. Objek Wisata Alam dan Pantai: Pantai Mutun, Paralayan, Pulau Tangkil, arung jeram, wisata bahari, agro wisata, pemandian, Pantai Gisting, Bendungan Batu Tegi, Gunung Rajaada, Air terjun Way Lahan, Danau Suoh, Danau Tirta Gangga, dan Air Terjun Curup Tujuh.

2. Objek Wisata Budaya: seni tari kulintang, cangget, piring, buban during, tupping, dan tari kenui; Festival Teluk Semaka, Krakatau Festival, Festival Teluk Sambas, dan Pesona Lumbok Banau; Upacara Ngumbay Lawok, Upacara Pengetahan Adok, dan Hajat Laut.

3. Objek Wisata Religi: Vihara Hin Bio, Gereja Marturia, Makam Raden Intan, Situs Purawiwitan, Kompleks Megalitik, Masjid Al-Anwar, dan Masjid Al-Yagin.

4. Objek Wisata Kerajinan: Tapis, batik Sanggi, Sulam Usus, dan kain Inuh.

5. Objek Wisata Kuliner : durian tanggamus, keripik pisang, seruit, nyubik, kopi, dan kerupuk kemplang.
6. Objek Wisata Sejarah : Situs Pugung Raharjo, Kota Tulang Bawang, Monumen Krakatau, Museum Lampung, Rumah Adat Lampung, Monumen Krakatau, dan Museum Negri Ruwai Jurai.

Jika dikaji lebih dalam sesuai dengan konsep Edward Inskeep (1991:80), maka objek daya tarik wisata (ODTW) di Lampung terdiri atas 3 kategori, yakni:

1. Daya tarik alam meliputi keindahan pantai, laut, kekayaan flora fauna, lingkungan yang khas seperti laguna, gumuk pasir, batu karang, taman karang, danau, pegunungan, dan pasir putih.

2. Daya tarik budaya meliputi kesenian tradisional, kuliner, kerajinan tapis, rumah adat, dan upacara adat.

3. Daya tarik sejarah meliputi peninggalan situs, makam keramat, masjid, dan museum.

Semua objek wisata akan dilakukan penilaian meliputi kriteria keragaman atraksi, latar lingkungan alam budaya, tingkat kelola lingkungan, hubungan antara objek wisata, aksebilitas, fasilitas, pasar kelembagaan, dan SDM. Selanjutnya hasil dari penilaian semua komponen ODTW akan dikaji dengan menggunakan analisis SWOT yakni merupkan salah satu alat menganalisis kekuatan (strength), kelemahan (weakness), peluang (opportunity) dan ancaman (threat) suatu objek. Analisis SWOT digunakan pada data yang tidak menggunakan angka (kualititatif) dan digunakan sebagai dasar dalam perumusan kebijakan.

Kelemahan dan kekuatan berasal dari faktor internal yang ada pada saat ini, yang memberi dampak positif dan negatif bagi keberhasilan program wisata di Lampung. Adapun peluang dan ancaman berasal dari faktor eksternal yang memberi dampak positif atau negatif bagi kelangsungan program wisata di Lampung. 
Hasil dari penilaian komponen OTDW di Lampung dengan menggunakan analisis SWOT adalah sebagai berikut :

1. Objek Wisata Alam (Laut) meliputi Pantai Mutun, Paralayan, Pulau Tangkil, arung jeram, wisata bahari, agro wisata, pemandian, Pantai Gisting, Bendungan Batu Tegi, Gunung Rajaada, Air terjun Way Lahan, Danau Suoh, Danau Tirta Gangga, dan Air Terjun Curup Tujuh.

\section{Kekuatan (Strenght):}

- Memiliki keindahan pantai, batu karang, gunung, dan laguna.

- Deburan ombak tidak terlalu keras, bisa dipakai camping ground, pemancingan, renang dan perahu dayung.

- Keindahan pasir putih di sekitar pantai.

- Lingkungan geografis masih asli dan alami.

- Kesejukan udara alam di sekitar pantai.

- Tingkat pencemaran alam relatif kecil.

- Orbitasi dengan objek wisata lain relatif dekat.

- Kondisi jalan relatif bagus.

- Sudah terdapat dalam paket brosur Wisata.

- Diminati masyarakat baik dalam maupun luar negeri.

- Sudah tersebar dari mulut ke mulut.

- Adanya keterlibatan antarsektor dalam pengembangan atau pengelolaan (Disbudpar, Bappeda)

- Sudah ada pemandu yang menguasai medan

\section{Kelemahan (Weakness)}

- Belum terbentukmya brand image di kawasan wisata Lampung.

- Kondisi masyarakat yang belum menunjang keberadaan pantai misalnya sampah terlihat menumpuk, pencarian rumput laut yang liar bisa mengganggu ekosistem, dan sikap masyarakat yang kurang simpati seperti adanya minta uang dengan paksa dan meminta bayaran agak mahal.
- Belum semua terjangkau dan tersedia mobil umum sampai ke lokasi.

- Belum semua tersedia fasilitas umum seperti WC, kamar mandi, sarana pendukung keselamatan jika ada kecelekaan/tenggelam dan poliklinik.

- Tempat parkir belum semua tersedia.

- Belum semua jalan bagus, artinya perlu perbaikan.

- Letak yang cukup jauh memerlukan transportasi memadai.

- Belum semua lokasi wisata tersedia penginapan.

- Belum semua tersedia guide yang profesional.

\section{Peluang (Opportunities)}

- Memiliki potensi yang tinggi berupa unsur kelautan (wisata pantai).

- Kekayaan laut dapat dikelola secara optimal untuk kesejahteraan masyarakat.

- Dapat dikembangkan objek wisata baru berupa perkemahan, pendakian gunung, pemancingan, camping ground, renang, perahu dayung dan selancar.

- Dibuat paket wisata.

- Mengembangkan desa wisata.

- Dapat dirancang perencanaan pengadaan alat transportasi umum dan sarana kesehatan untuk menanggulangi kecelakaan atau dalam menghadapi situasi darurat.

- Dapat dirancang untuk membangun fasilitas umum.

- Jumlah pengunjung diperkirakan akan meningkat di waktu mendatang.

- Dapat mengundang stakholder swasta (investor) untuk menanamkan modal (investasi).

- Kebijakan yang menjadikan usaha pariwisata di satuan kawasan wisata Lampung sebagai sektor unggulan.

\section{Ancaman (Threatness)}

- Akan muncul budaya baru yang kontemporer seperti komersialisme, materialistis dan vandalisme. 
- Dikhawatirkan adanya tingkat kerusakan lingkungan.

- Rawan kecelakaan di laut, kejahatan dan mungkin terdapat lokalisasi prostitusi.

- Tingkat kesadaran masyarakat yang mendukung perawatan fasilitas masih rendah.

- Kemungkinan terjadi konflik.

- Minat wisatawan asing masih minim, karena belum tersedianya sarana yang menunjang seperti hotel, penukaran uang, restoran yang luas, dan faktor jarak yang cukup jauh, berkelok cukup menyulitkan perjalanan.

- Kinerja pariwisata hanya diukur dari perolehan PAD.

- Keamanan kurang pada tempat tertentu.

2. Objek Wisata Budaya yang berupa kesenian (seni tari kulintang, cangget, piring, buban during, tupping, dan tari kenui); Festival Teluk Semaka, Krakatau Festival, Festival Teluk Sambas, dan Pesona Lumbok Banau; Upacara Adat Ngumbay Lawok, Upacara Pengetahan Adok, dan Hajat Laut; Kampung Adat Kampung Wana; Kerajinan (kain tapis, batik sanggi, sulam usus, tenun inuh), dan makanan khas (durian tanggamus, keripik pisang, seruit, nyubik, kopi, dan kerupuk kemplang).

\section{Kekuatan (Strength)}

- Upacara dan kesenian tradisional merupakan khasanah budaya yang sangat menarik, unik, dan memiliki kekhasan. Pelaksanaan upacara tradisional merupakan atraksi budaya yang memiliki nilai filosofi tinggi, sakral, dan meriah serta melibatkan hampir semua komponen masyarakat sehingga memiliki daya tarik wisatawan asing maupun lokal.

- Adanya makanan khas yang enak dan kain tapis merupakan hasil industri rumahan masyarakat
- Adanya kampung adat di Desa Wana bisa dikembangkan menjadi objek wisata budaya karena memiliki adat istiadat dan arsitektur rumah yang menarik.

- Kehidupan masyarakat nelayan lengkap dengan tradisinya yang unik menarik wisatawan.

\section{Kelemahan (Weakness)}

- Pelaksanaan upacara adat dan kesenian tradisional belum dikemas dengan baik.

- Makanan khas belum dikemas dengan baik dan pemasaran kurang maksimal.

- Belum banyak tempat khusus untuk penjualan cinderamata bagi wisatawan.

- Belum ada promosi tentang adanya kampung adat.

\section{Peluang (Opportunites)}

- Memiliki potensi budaya yang tinggi..

- Dapat dikembangkan objek wisata berupa pengembangan desa wisata dan kampung adat.

- Bisa dibangun work shop atau art centre (pasar seni) untuk memasarkan hasil kriya masyarakat setempat.

- Jika dikemas dan promosi dengan baik, maka makanan khas dan kerajinan tradisional bisa lebih populer dan dicari wisatawan.

- Dapat mengundang investor untuk menanamkan modal.

- Jumlah pengunjung lebih meningkat, sehingga pendapatan PAD tercapai.

\section{Ancaman (Threatness)}

- Dikhawatirkan pelaksanaan upacara adat dan kesenian tradisional yang dikemas secara berlebihan bisa mengurangi nilai keaslian dan kesakrakalan, sehingga nilai lama memudar.

- Bila tidak ditangani hati-hati, maka nilai baru bisa merusak tatanan kehidupan masyarakat kampung adat.

3. Objek Wisata Sejarah meliputi Situs Pugung Raharjo, Kota Tulang Bawang, Monumen Krakatau, Museum 
Lampung, bangunan bersejarah, Monumen Krakatau, dan Museum Negri Ruwai Jurai, Vihara Hin Bio, Gereja Marturia, Makam Raden Intan, Situs Purawiwitan, Kompleks Megalitik, Masjid Al-Anwar, dan Masjid Al-Yagin.

\section{Kekuatan (Strength)}

- Bangunan bersejarah, situs purbakala, museum, dan masjid tua memiliki nilai kesejarahan yang tinggi.

- Makam keramat dan situs purbakala memiliki daya tarik spiritual bagi kelompok masyarakat tertentu.

\section{Kelemahan (Weakness)}

- Perawatan kurang.

- Petugas terbatas.

- Banyak terjadi pencurian (hilang) benda-benda purbakala.

- Letak cukup jauh, hingga memerlukan sarana transportasi khusus.

- Terkadang disalahgunakan untuk kepercayaan tertentu.

\section{Peluang (Opportunties)}

- Dapat dikembangkan sebagai objek wisata religi.

- Dewasa ini minat untuk mengunjungi objek wisata sejarah dan religi meningkat dengan tajam, baik di dalam maupun di luar negeri.

- Terdapat unsur pendidikan.

- Bisa dijadikan muatan lokal di sekolah.

\section{Ancaman (Threatness)}

- Jika tidak hati-hati dijaga akan terjadi kerusakan atau kehilangan pada bendabenda purbakala.

\section{Rencana Pengembangan}

Analisis SWOT dilaksanakan setelah diperoleh data dari lapangan. Analisis SWOT adalah suatu metode yang digunakan untuk mendapatkan suatu pemahaman tentang kemampuan suatu objek, perorangan atau lembaga, dalam hal ini objek wisata. Konsep ini memberikan suatu pandangan dasar tentang pengembangan di bidang kepariwisataan. Analisis ini akan menghasilkan beberapa skenario pengembangan. Skenario ini didapatkan dengan mengembangkan atau meningkatkan potensi dan meraih peluang setinggi-tingginya. Selain itu untuk mengurangi kelemahan dan menghilangkan ancaman. Dari beberapa skenario ini dapat dirumuskan arahan strategi sebagai berikut:

\section{Strategi pertama Ekspansi : Memanfaatkan secara maksimal kelautan meraih peluang}

Potensi alam yang ada di kawasan Lampung dan sekitarnya dapat dikembangkan menjadi objek wisata alam, pantai bahari (kelautan), budaya, hutan (ekowisata), kebun (agrowisata) dan wisata buatan seperti arena bermain, motorcross, olahraga, pemancingan, renang dan lain sebagainya. Peluang yang dicapai menjadikan Kota Lampung sebagai salah satu tujuan wisata dan untuk meningkatkan PAD dalam rangka otonomi daerah yang pada akhirnya untuk meningkatkan kesejahteraan masyarakat. Untuk itu diperlukan infrastruktur yang dapat mendukung pengembangan wisata tersebut, di antaranya perbaikan jalan, kendaraan umum, pelabuhan pendaratan ikan, pemukiman nelayan, fasilitas umum MCK, penginapan, restoran yang memadai, informasi dan telekomunikasi, pusat pembelanjaan, perbankan, tempat parkir, turis informasi dan penukaran uang. Infrastruktur yang sudah ada tinggal diperbaiki atau dibangun kembali. Untuk semua itu memang perlu dana yang tidak sedikit dan waktu cukup lama. Oleh sebab itu pemerintah atau lembaga yang terkait perlu menangani lebih serius. Penggalian dana bisa lewat kemitraan atau partnership, jalur marketing dan networking, baik pemerintah maupun investor asing. Dukungan masyarakat setempat juga sangat diharapkan dalam 
rangka mewujudkan sadar wisata, karena itu masyarakat setempat perlu dilibatkan dan pembangunan disesuaikan dengan budaya lokal.

\section{Strategi kedua Diversifikasi : Memanfaatkan secara maksimal kekuatan untuk mengantisipasi dan menghadapi ancaman}

Penguatan program pembinaan atau pelatihan yang diarahkan pada masyarakat dan petugas wisata untuk sadar wisata. Mengembangkan profesionalisme SDM pariwisata yang berwawasan global tanpa menghilangkan identitas budaya lokal. Untuk menjaga kelestarian hutan, pantai dan budaya diharapkan masyarakat mematuhi adanya larangan atau anjuran yang biasa ditulis di pamflet, plang atau brosur. Membangun jaringan pemasaran produk wisata untuk menarik kunjungan dan membangun koordinasi antarsektor dan database keparawisataan.

\section{Strategi ketiga Konsolidasi Internal : Mengurangi kelemahan untuk mencari peluang}

Memperbaiki sarana dan prasarana pariwisata yang belum ada atau belum memadai. Mengemas paket wisata agar layak untuk dinikmati wisatawan, tanpa mengurangi keaslian, kesakralan, tatanan/adat dan kelestarian budaya lokal. Rekruitmen SDM yang berkualitas atau mengembangkan program pendidikan di bidang keparawisataan.

\section{Strategi keempat Introspeksi : Mengurangi kelemahan untuk menghindari ancaman}

Menguatkan aturan Perda di Lampung agar pelaksanaan otonomi tidak mengancam pelestarian sumber data pariwisata serta kinerja pariwisata tidak harus diukur dari perolehan PAD. Menyebarluaskan jadwal kegiatan wisata (calendar of event) seperti pelaksanaan hajat laut, tasyakuran nelayan, festival kuliner, kesenian tradisional, dan lain sebagainya. Agar kekhawatiran akan sedikitnya kunjungan wisata tidak terjadi. Menghilangkan citra negatif seperti adanya aji mumpung, yakni harga dimahalkan, minta uang dengan paksa dan sifat cepat tersinggung di kalangan masyarakat setempat, agar terbentuk brand image atau citra yang positif bagi pariwisata di Lampung

Strategi yang disusun tersebut sesungguhnya merupakan satu kesatuan strategi yang diharapkan dapat mewujudkan visi dan misi pengembangan pariwisata di Lampung.

\section{PENUTUP}

Dalam mengantisipasi era otonomi daerah yang menuntut kemandirian dalam melakukan kegiatan pembangunan, pemerintah Provinsi Lampung menggali dan memanfaatkan seluruh potensi yang ada di daerah agar dapat meningkatkan PAD dan pada akhirnya diharapkan dapat menyejahterakan masyarakatnya. Dari hasil penelitian dan kajian, bisa ditarik kesimpulan bahwa:

1. Potensi yang ada di satuan kawasan wisata Lampung perlu dikembangkan dengan melihat kekuatan, kelemahan, peluang dan ancaman pada ODTW (objek daerah tujuan wisata) tersebut.

2. Meningkatkan dan melakukan sarana fisik dan manjemen ODTW.

3. Membangun citra pariwisata dengan menitikberatkan wisata alam, budaya, religi, dan wisata sejarah. Dalam pengembangan juga bisa menjadi wisata desa, agro wisata, kampung adat atau nelayan, ritual, kuliner, tari tradisional dan wisata kriya (hasil kerajinan).

4. Membangun data base, koordinasi lintas sektoral dan jaringan pemasaran.

5. Membangun format pemberdayaan SDM yang sadar wisata dan berwawasan global tanpa menghilangkan identitas budaya lokal. 
6. Dalam pembangunan dan pengemasan produk wisata tetap menjaga kelestarian dan keaslian budaya lokal.

7. Pengembanan wisata tidak hanya melihat keindahan alam saja, tapi juga melihat kehidupan sosial budaya masyarakat setempat. Seperti halnya di Bali, ketertarikan wisatawan lebih pada kehidupan sosial budaya masyarakatnya yang khas. Oleh karena itu pengembangan kepariwisataan diarahkan pada wisata desa yakni masyarakat nelayan dan kampung adat.

8. Pariwisata lebih dikembangkan, mengingat wisatawan senang akan pengalaman dan petualangan yang menantang.

9. Perlu revitalisasi kesenian tradisional, yakni dengan mengadakan pelatihan bagi generasi muda, memberi fasilitas sarana alat dan tempat bagi pelatihan kesenian tradisional.

10. Kampung adat bisa dikembangkan sebagai kampung wisata dengan melihat keunikan adat istiadat yang masih dilakukan masyarakat adat.

Demikianlah, Provinsi Lampung memiliki potensi wisata yang cukup besar, karena memiliki objek dan daya tarik wisata yang cukup lengkap yakni objek wisata alam, sejarah, dan wisata budaya. Objek wisata yang tercatat cukup banyak tersebar di 13 Kabupaten, yang tentu saja belum semua tercatat dengan baik. Selain objek wisata yang perlu dikembangkan, terdapat pula potensi pendukung pariwisata yang perlu diperhatikan yakni potensi sumber daya manusianya, sikap mental dan nilai-nilai budaya yang berkaitan dengan Sapta Pesona Pariwisata. Terakhir, potensi wisata di Lampung khususnya wisata nonunggulan perlu dikembangkan dengan baik, karena selain menambah devisa negara, memperluas lapangan kerja, dan memperkenalkan serta melestarikan aneka ragam budaya serta alam Indonesia yang indah.

\section{DAFTAR SUMBER}

Ahimsa, Heddy Shri. 1999.

"Perencanaan Wisata Budaya"

Modul bimbingan teknis perencanaan program kepariwisataan, diselenggarakan oleh pusat Penelitian dan Pengembangan Pariwisata UGM.

Budi Santosoo. 1989.

"Pariwisata dan Perkembangan Pengembangan Pariwisata". Makalah: P2NB.

Hadikusuma, Hilman. 1989.

"Masyarakat dan Adat Istiadat Lampung”. Bandung: Mandar Maju.

Nyoman S. Pandit. 2001.

"Ilmu Pariwisata". Sebuah Pengantar Perdana, Jakarta: PT Pradnya Paramita. 2003

"Pariwisata Sebuah Studi, Analisa dan Informasi". Jakarta: Djambatan

Rocek Waren. 2002.

"The Tourist". Antologi Kepariwisataan di Indonesia. Jakarta: Press.

Seda, Frans. 2001.

"Pengembangan Pariwisata dan Lingkungan Hidup", Makalah pada lokakarya Musyawarah Nasional VII PHRI, Sanur-Bali.

Susanto, Astrid S. 1996.

"Pariwisata dan Perubahan Sosial Budaya", dalam Majalah Teknis Pariwisata, Direktorat Jenderal Pariwisata, Jakarta, Vol 1 no 1. 
Sitorus, dkk. 1999.

"Peranan Kebudayaan Daerah Lampung dalam Mewujudkan Masyarakat Industri Daerah Lampung”. Kanwil Depdikbud Provinsi Lampung.

Fachrudin. 1996.

"Falsafah Piil Pesenggiri Sebagai Norma Tatakrama Kehidupan Sosial Masyarakat Lampung”. Lampung: P3NB Lampung. 